\title{
EST Mining and Functional Expression Assays Identify Extracellular Effector Proteins From the Plant Pathogen Phytophthora
}

\author{
Trudy A. Torto, ${ }^{1}$ Shuang Li, ${ }^{2}$ Allison Styer, ${ }^{1}$ Edgar Huitema, ${ }^{1}$ Antonino Testa, ${ }^{1}$ Neil \\ A.R. Gow, ${ }^{2}$ Pieter van West, ${ }^{2}$ and Sophien Kamoun ${ }^{1,3}$ \\ ${ }^{1}$ Department of Plant Pathology, The Ohio State University, Ohio Agricultural Research and Development Center, Wooster, \\ Ohio 44691, USA; ${ }^{2}$ Department of Molecular and Cell Biology, Institute of Medical Sciences, Foresthill AB25 2ZD, \\ Scotland, UK
}

\begin{abstract}
Plant pathogenic microbes have the remarkable ability to manipulate biochemical, physiological, and morphological processes in their host plants. These manipulations are achieved through a diverse array of effector molecules that can either promote infection or trigger defense responses. We describe a general functional genomics approach aimed at identifying extracellular effector proteins from plant pathogenic microorganisms by combining data mining of expressed sequence tags (ESTs) with virus-based high-throughput functional expression assays in plants. PexFinder, an algorithm for automated identification of extracellular proteins from EST data sets, was developed and applied to 2147 ESTs from the oomycete plant pathogen Phytophthora infestans. The program identified 261 ESTs (12.2\%) corresponding to a set of 142 nonredundant Pex (Phytophthora extracellular protein) cDNAs. Of these, 78 (55\%) Pex cDNAs were novel with no significant matches in public databases. Validation of PexFinder was performed using proteomic analysis of secreted protein of $P$. infestans. To identify which of the Pex cDNAs encode effector proteins that manipulate plant processes, high-throughput functional expression assays in plants were performed on 63 of the identified cDNAs using an Agrobacterium tumefaciens binary vector carrying the potato virus X (PVX) genome. This led to the discovery of two novel necrosis-inducing cDNAs, $c r n 1$ and $c r n 2$, encoding extracellular proteins that belong to a large and complex protein family in Phytophthora. Further characterization of the crn genes indicated that they are both expressed in $P$. infestans during colonization of the host plant tomato and that $\mathrm{crn} 2$ induced defense-response genes in tomato. Our results indicate that combining data mining using PexFinder with PVX-based functional assays can facilitate the discovery of novel pathogen effector proteins. In principle, this strategy can be applied to a variety of eukaryotic plant pathogens, including oomycetes, fungi, and nematodes.
\end{abstract}

[Supplemental material is available online at www.genome.org and http://www.oardc.ohio-state.edu/ phytophthora/supp.htm. The sequence data from this study have been submitted to GenBank under accession nos. AF424638-AF424690.]

Interactions between plants and microbial pathogens involve complex signal exchanges at the plant surface and intercellular space interface (Baker et al. 1997; Parniske 2000; Hahn and Mendgen 2001). For example, plant pathogens have the remarkable ability to manipulate biochemical, physiological, and morphological processes in their host plants through a diverse array of extracellular effector molecules that can either promote infection or trigger defense responses (Knogge 1996; Lauge and De Wit 1998; Collmer et al. 2000; Kjemtrup et al. 2000; Staskawicz et al. 2001). Typically, such molecules are secreted into the intercellular interface between the pathogen and the plant or delivered inside the host cell to reach their cellular target. Thus, discovery programs that target genes encoding extracellular proteins can be expected to increase the probability of identifying genes involved in virulence. This approach has been taken successfully in the study of bacterial

\section{${ }^{3}$ Corresponding author.}

E-MAIL kamoun.1@osu.edu; FAX (330) 263-3841.

Article and publication are at http://www.genome.org/cgi/doi/10.1101/ gr.910003. pathogens and symbionts. For example, an early study showed that Sinorhizobium meliloti mutants deficient in extracellular proteins were five times more likely to be affected in symbiosis than random mutants (Long et al. 1988). More recently, the characterization of effector proteins secreted through the type III secretion system of animal- and plantassociated bacteria has emerged as a key strategy for understanding mechanisms of virulence (Collmer et al. 2000; Kjemtrup et al. 2000; Staskawicz et al. 2001). In eukaryotic plant pathogens, genomic studies that focus systematically on extracellular proteins remain limited to nematodes, in which secretions from the esophageal gland cells are thought to play critical roles in infection (Wang et al. 2001). However, several classes of oomycete and fungal effector molecules, such as elicitor proteins that induce plant defense responses and a programmed cell death response termed the "hypersensitive response" (HR), are known to require secretion (Lauge and De Wit 1998; Jia et al. 2000). Therefore, secretion is an essential mechanism for delivery of virulence factors by eukaryotic plant pathogens to their appropriate site in infected plant tissue. 
In eukaryotic cells, most secreted and membrane proteins are exported through the general secretory pathway (also known as type II secretion system) via short, N-terminal amino-acid sequences known as signal peptides (von Heijne 1985; Rapoport 1992). Typically, signal peptides contain one or two charged amino acids followed by a hydrophobic core, and the signal peptidase cleavage site is defined by a pair of small uncharged amino acids (von Heijne 1985). Although most of these features can be identified in known extracellular proteins, the particular amino acid sequences are highly degenerate, and cannot be identified using DNA hybridization or PCR-based techniques (Klein et al. 1996). However, with the advent of genomics, large sets of sequence data became available, creating the opportunity to develop and test predictive software to identify extracellular proteins. For example, SignalP v2.0, a program that was developed using machine learning methods, assigns signal peptide prediction scores and putative cleavage sites to unknown amino acid sequences with a high level of accuracy (Nielsen et al. 1997; Nielsen and Krogh 1998; Menne et al. 2000).

The Irish famine pathogen, Phytophthora infestans, is a eukaryotic oomycete microorganism that causes late blight, a worldwide devastating disease of potato and tomato (Fry and Goodwin 1997a,b). Although it is a pathogen of great economic importance, little is known about the molecular mechanisms involved in the pathogenicity and host specificity of $P$. infestans, and only a handful of genes have been implicated in interaction with host plants (Kamoun 2000, 2001). Structural genomics of Phytophthora is underway. Pilot cDNA sequencing projects were performed for $P$. infestans and another species, Phytophthora sojae (Kamoun et al. 1999b; Qutob et al. 2000), resulting in a database of expressed sequence tags (ESTs; Waugh et al. 2000). With the accumulation of sequence data for Phytophthora, the challenge is shifting to data mining and functional analyses. One important goal is to be able to associate a biological function with sequences with no significant similarity to known genes. With this objective in mind, we set up to identify systematically $P$. infestans cDNAs encoding extracellular proteins from EST databases. Here, we describe PexFinder, an algorithm for the automated identification of putative extracellular proteins from ESTs. We applied PexFinder to a $P$. infestans EST data set and selected 63 candidate Pex (Phytophthora extracellular proteins) cDNAs for functional expression in plants using a viral vector. This functional genomics strategy resulted in the discovery of a novel family of necrosis-inducing genes that are predicted to encode extracellular proteins with no similarity to sequences in public databases.

\section{RESULTS}

\section{PexFinder: An Algorithm for the Automated Identification of Extracellular Proteins From ESTs}

To identify signal peptides from ESTs, we developed an algorithm, PexFinder, which integrates a series of sequence analysis and data manipulation programs with SignalP v2.0, a program that predicts the presence of signal peptides and their cleavage sites using artificial neural networks (SignalP-NN) and hidden Markov models (SignalP-HMM; Nielsen et al. 1997; Nielsen and Krogh 1998). The PexFinder pipeline is illustrated in Figure 1. Inputs to the pipeline were edited nucleotide sequences (5' ESTs) in the FASTA format (Pearson 1990). These sequences were scanned for start codons (ATG),

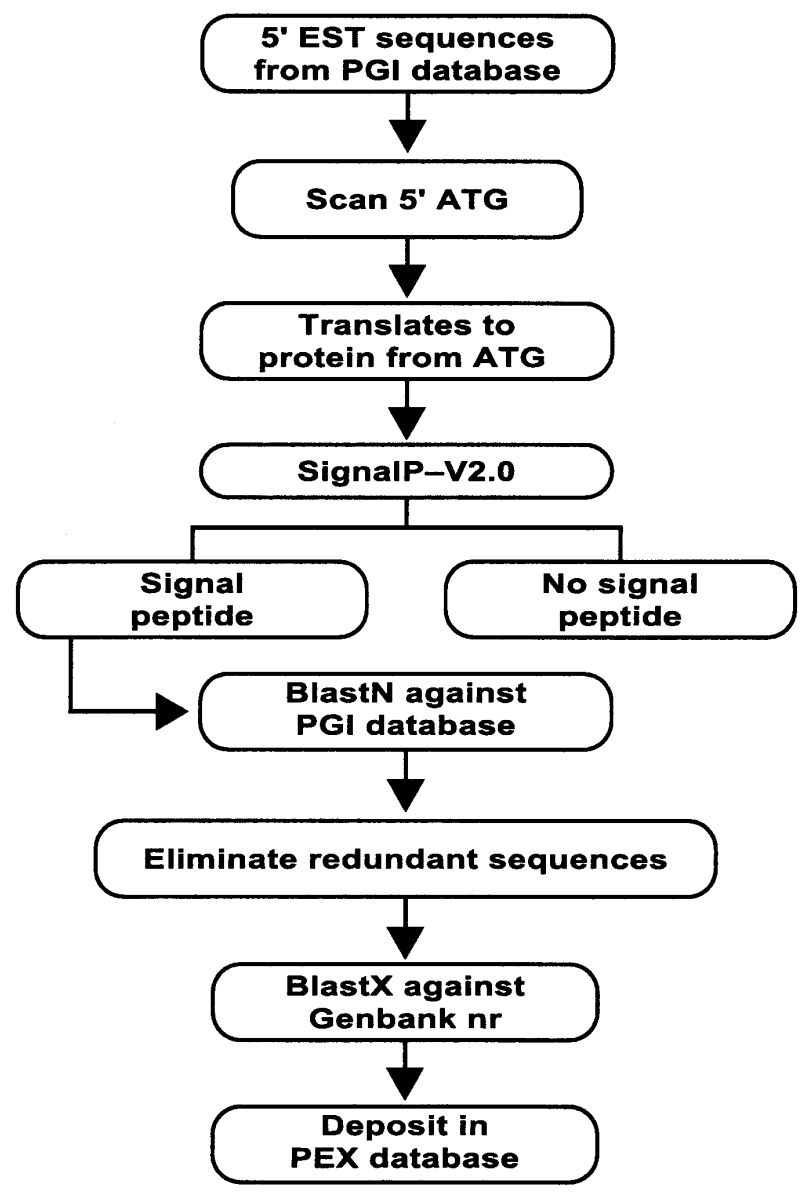

Figure 1 Schematic of the PexFinder algorithm for identification of extracellular proteins from expressed sequence tags (ESTs). The various steps of the algorithm are explained in the text. The programs as well as detailed instructions can be obtained from http:// www.oardc.ohio-state.edu/phytophthora/pexfinder.

the first 70 codons were translated, and an output file was generated in a format that can be read by SignalP v2.0. Following SignalP v2.0 analysis, the output files were manipulated to select for signal peptides containing sequences using the following two criteria: (1) SignalP-HMM prediction is "Signal Peptide", and (2) SignalP-NN predicts a cleavage site between 10 and 40 amino acids in length. An output file containing only those ESTs that were identified as signal-peptide positives was generated. These ESTs were then queried against the original EST database using the BLASTN algorithm (Altschul et al. 1997) to check for and eliminate redundant sequences. Nonredundant sequences predicted to encode extracellular proteins were queried against the GenBank nonredundant database using BLASTX (Altschul et al. 1997) for annotation.

\section{PexFinder Processing of $P$. infestans ESTs}

We analyzed a total of 2147 ESTs from $P$. infestans (GenBank accession nos. BE775444-BE777460) using PexFinder. We found that 261 ESTs corresponding to 142 nonredundant sequences were predicted to contain signal peptide-like sequences (Supplementary Material Table S1, available online at www.genome.org). A scatter diagram of the predicted mean S

\section{Genome Research


scores of SignalP-NN and the scores of SignalP-HMM for the 142 selected ESTs showed clustering at the higher quadrant of the graph shown in Figure 2A. For comparison, we used SignalP v2.0 to analyze a set of 59 known and annotated oomycete proteins (Suppl. Table S2). A scatter diagram of the SignalP-NN and SignalP-HMM scores showed a clear separation of the cytoplasmic oomycete proteins from the extracellular ones (Fig. 2B). This suggests that the SignalP v2.0 program can identify unambiguously a signal peptide in oomycete sequences and that the selected ESTs are likely to encode putative extracellular proteins.

\section{Analysis of Selected Pex cDNAs}

Of the 142 nonredundant Pex cDNAs, 78 (55\%) were novel and showed no significant matches (E value $>10^{-5}$ ) to sequences in public databases, whereas the remaining 64 (45\%) showed significant hits (E value $<10^{-5}$ ), and 56 (39\%) of these could be assigned a putative function (Suppl. Table S1). To evaluate the performance of PexFinder, we assigned the most likely subcellular localization to 55 of the Pex cDNAs

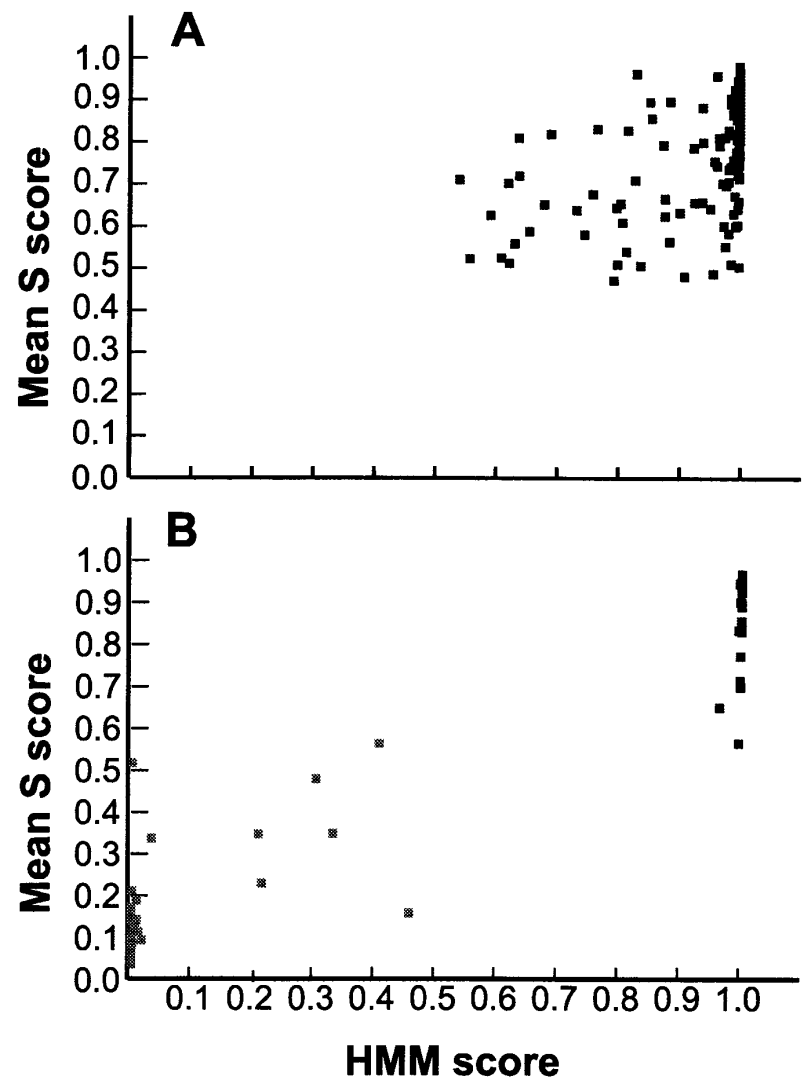

Figure 2 Scatter diagrams of output scores obtained with SignalP v2.0 for $(A) 142$ putative extracellular proteins identified from $P$. infestans using PexFinder, and (B) 59 known and annotated oomycete proteins. "HMM score": The prediction score obtained with the SignalP V2.0 hidden Markov model program. "Mean S score": The score obtained with the SignalP V2.0 neural network program. Scores for both programs range from 0 to 1 , with higher scores indicating a higher probability for a signal peptide. Sequences predicted to correspond to extracellular proteins based on annotation using the InterPro database (Apweiler et al. 2001), GenBank (Karsch-Mizrachi and Ouellette 2001), or literature review are shown as black boxes, and other sequences are shown as gray boxes. based on the functional identity of their best matches and independently of the SignalP scores (Suppl. Table S1). Of the 55 cDNAs, 40 (73\%) were predicted to encode extracellular- or membrane-associated proteins, as expected for proteins carrying functional signal peptides. Of these, 21 were predicted to encode extracellular proteins, 13 integral membrane proteins, and six proteins localized in the lumen of the endoplasmic reticulum. On the other hand, eight of the cDNAs were predicted to encode cytosolic protein, six mitochondrial protein, and one peroxisomal protein, suggesting that 15 (17\%) of the cDNAs were likely false positives. Eight ESTs corresponded to full-length cDNAs for known Phytophthora extracellular proteins, such as INF1 elicitin, elicitin-like proteins, cyst germination-specific protein, and necrosis-inducing protein. Ten ESTs were predicted to encode secreted enzymes or other products that may function in virulence. These include chitinase, arabinofuranosidase/ $\beta$-xylosidase, endo-glucanase, exo-glucanase, glycosyl hydrolase, peroxidase, protease, and thaumatin. A total of six cDNAs with no matches in public databases were predicted to encode cysteine-rich protein less than 150 amino acids in length, a feature typical of effector proteins involved in plant-microbe interactions (Templeton et al. 1994).

\section{Validation of PexFinder Using Proteomics}

We used proteomics of secreted proteins of $P$. infestans to further validate PexFinder. We collected filtrates from $P$. infestans cultures grown in a synthetic medium, precipitated the proteins with acetone, and subjected them to two-dimensional gel electrophoresis (Fig. 3). A total of 30 spots were excised from the gel, digested with trypsin, and subjected to peptide mass mapping using a MALDI-TOF mass spectrometer. Taking into account unsuccessful analyses and redundant spots, a total of 22 different peptide mass spectra were obtained. We then matched the observed masses of the peptides with predicted masses deducted from the 142 Pex cDNAs using the program Protein Prospector 3.2.1 (University of California). A total of nine proteins could be matched unambiguously to cDNAs identified using PexFinder (Fig. 3; Suppl. Table S1). These results provide experimental validation of the PexFinder algorithm.

\section{Functional Expression of Pex cDNAs in Plants}

Ectopic expression of single pathogen genes in plant cells often leads to phenotypic effects, such as induction of HR-like necrosis (Lauge and De Wit 1998; Kjemtrup et al. 2000). To identify Pex cDNAs that induce necrotic symptoms in plants, we developed a strategy for functional expression screening of selected $P$. infestans cDNAs in Nicotiana benthamiana using an A. tumefaciens binary potato virus X (PVX)-based vector (Fig. 4). $N$. benthamiana was selected because it is highly susceptible to PVX infection and exhibits HR-based resistance to $P$. infestans (Kamoun et al. 1998). We selected 63 Pex cDNAs, most of which correspond to sequences with no significant matches in GenBank (Suppl. Table S1), for cloning in the binary PVX expression vector pGR106 (Jones et al. 1999; http:// www.jic.bbsrc.ac.uk/Sainsbury-Lab/david-baulcombe/ Services/vigsprotocol.htm). The inserts of the 63 cDNAs were divided into eight pools of 4-10 clones and ligated to pGR106, resulting in an A. tumefaciens infection-ready minilibrary. A total of 760 clones were then inoculated in N. benthamiana, a plant species that is highly amenable to highthroughput PVX assays (Baulcombe 1999) and that is known 


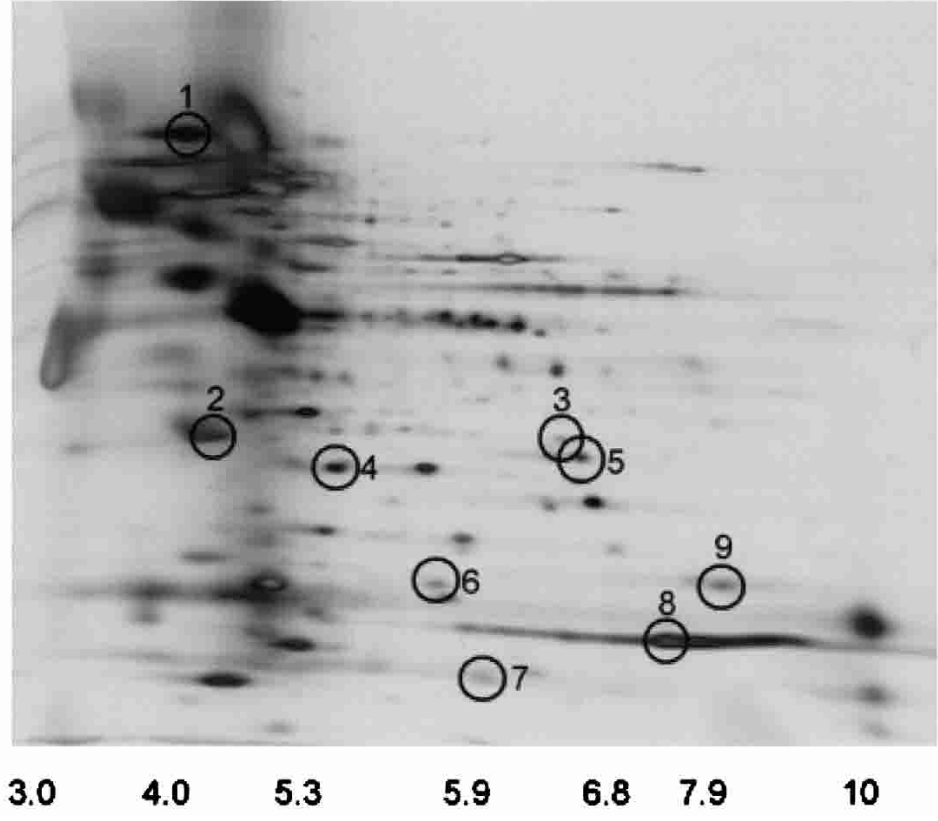

Figure 3 Two-dimensional gel electrophoresis analysis of secreted proteins of $P$. infestans. Circled spots highlighted by a number correspond to nine identified Pex proteins from a total of 30 spots analyzed using mass spectrometry of tryptic peptides. (1) BE777050, arabinofuranosidase/ $\beta$-xylosidase; (2) BE776562, acidic chitinase; (3) BE776874, enoyl Coenzyme A hydratase; (4,5) BE777263, glutathione-S-transferase; (6) BE776368, unknown protein; (7) BE776395, similar to P. sojae avr1b; (8) BE777082, unknown protein; (9) BE776294, peptidylprolyl isomerase.

to display resistance responses to $P$. infestans (Kamoun et al. 1998; Kamoun 2001). Phenotypic evaluation of plants infected with the recombinant PVX identified eight clones that induced necrotic symptoms at the inoculation site, as well as necrosis and crinkling in systemic leaves. Partial DNA sequencing and restriction fragment analyses of the inserts of the eight clones revealed that they correspond to two cDNAs, named crn1 (two clones) and crn2 (six clones) for crinkling and necrosis. Additional infection assays with PVX:: $\overline{c r} 1$ and PVX::crn2 confirmed that both cDNAs consistently induced necrotic symptoms in $N$. benthamiana, whereas only mosaic symptoms were observed following inoculation with the empty vector (Fig. 5). Symptoms induced by PVX::crn2 started at about 5-7 d after inoculation, depending on the age of the plant and leaves, and generally developed 7-8 d faster than symptoms induced by PVX::crn1. Additional infection assays with PVX::crn1 and PVX::crn2 on solanaceous plants showed that the induction of necrosis was not specific to $N$. benthamiana, but also occurred on the nonhost plant tobacco (Nicotiana tabacum) and the host plant tomato (Lycopersicon esculentum; data not shown). On these plants, symptoms also varied in intensity, with $\mathrm{crn} 2$ always causing faster and more severe necrosis than $\mathrm{crn} 1$.

\section{crn1 and crn2 Are Members of a Large and Complex Gene Family in Phytophthora}

The full sequence of the $\mathrm{crn} 1$ and $\mathrm{crn} 2 \mathrm{cDNAs}$ was determined. crn1 sequence revealed a 1296-bp open reading frame (ORF) encoding a predicted protein composed of 431 amino acids, whereas crn2 revealed a 1371-bp ORF encoding a predicted protein composed of 456 amino acids. BLASTP searches
$\mathrm{kDa}$ against public databases revealed no similarity to proteins from other organisms, and searches for conserved protein motifs were unsuccessful. However, CRN1 and

67.0 CRN2 shared significant similarity to each other (Fig. 6), and TBLASTN searches against current EST databases of Phytophthora revealed that both proteins corre-

43.0 spond to a large family in Phytophthora with at least 34 different members (Suppl. Table S3). Multiple alignment of the 34 CRN-like sequences from $P$. infestans, $P$. sojae, and $P$. medicaginis indicated a significant degree of homology between the $\mathrm{N}$-terminal region of the different proteins (Suppl. Fig. S1). Twenty-eight of the 33

20.1 full-length CRN-like proteins were predicted to contain signal peptides using SignalP v2.0 (Suppl. Table S3).

14.4 The crn Genes Are Expressed During Colonization of Tomato by

\section{P. infestans}

To determine whether the crn genes are expressed during colonization of plants, we analyzed the expression of $\mathrm{crn} 1$ and crn2 during the interaction of $P$. infestans with its host plant tomato. Total RNA was isolated from leaves of tomato $0,1,2,3$, and $4 \mathrm{~d}$ after inoculation with $P$. infestans 90128 and from $P$. infestans mycelium grown in liquid rye-sucrose medium. A northern blot containing these samples was hybridized with probes of the $P$. infestans $\mathrm{crn}$ and actA genes (Fig. 7). Because the total RNA extracted from infected leaves consists of a mixture of Phytophthora and plant RNA, the signals obtained on northern blots with probes of differentially expressed genes should be normalized to actual Phytophthora RNA levels as determined by the signals obtained with the probe of a constitutively expressed actin gene. Consistent with increases in mycelial biomass during the infection, actA transcripts were first detected at day 2 and reached maximal levels at days 3 and 4. A pattern of expression identical to that of actA was observed for both $\mathrm{crn}$ genes, suggesting that these genes are constitutively expressed during colonization of tomato and in in vitro-grown mycelium.

\section{Comparison of Necrosis Induction by crn to Known Phytophthora Elicitors}

We compared the timing and appearance of the necrotic symptoms induced by the $\mathrm{crn}$ genes to those induced by known Phytophthora defense-response elicitors, such as $P$. infestans INF1 (Kamoun et al. 1998, 1999a) and P. sojae sojNIP (Qutob et al. 2002). PVX recombinants expressing crn1, crn2, inf1, and PsojNIP were inoculated side-by-side on mature leaves of $N$. benthamiana and examined for necrotic symptoms (Fig. 8). The first symptoms were observed with PVX:: inf1 and PVX::PsojNIP as early as $5 \mathrm{~d}$ after inoculation. In contrast, PVX::crn2- and PVX::crn1-inoculated plants started developing necrosis about 7 and $12 \mathrm{~d}$ after inoculation, respectively. Compared to PVX::inf1 and PVX::PsojNIP, which induced dark necrotic lesions around the site of inoculation,

\section{Genome Research




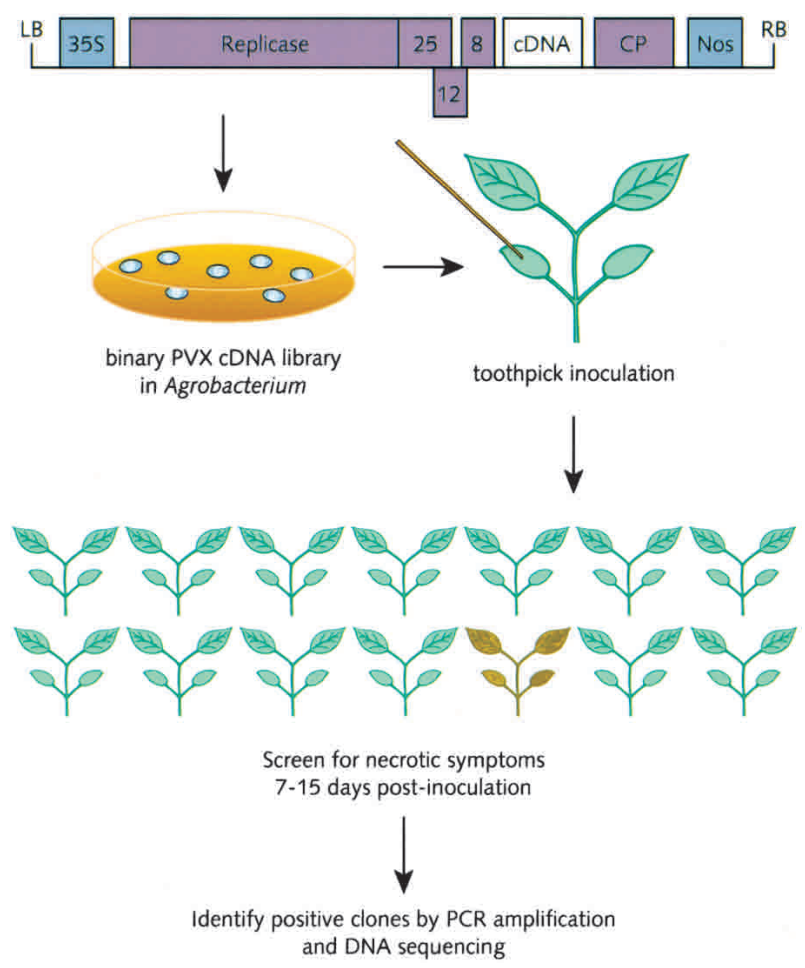

Figure 4 Strategy for functional screening of $P$. infestans CDNAs using agroinfection with a binary potato virus $X(P V X)$ vector. Pools of candidate CDNAs were ligated to the binary PVX vector, and electroporated into $A$. tumefaciens to generate infection-ready mini-libraries. Leaves of $N$. benthamiana plants were then toothpick-inoculated with individual clones. Clones inducing necrotic symptoms were identified by PCR amplification and sequencing.

the necrotic lesions induced by PVX::crn2 started off as light brown lesions which developed over time to have darker margins.

\section{crn2 Induces the Expression of Defense Response Genes in Tomato}

To determine whether the $\mathrm{crn}$ genes induce defense responses in plants, we inoculated tomato plants with PVX::crn1, PVX: crn2, and used the following as negative controls: mock inoculation, the empty PVX vector pGR106, and PVX carrying the $P$. infestans inf1 gene, which does not induce necrosis on tomato (Kamoun et al. 1999a). Twelve d after inoculation, total RNA was isolated from tomato leaves systemically infected with PVX virions or the equivalent leaves from mockinoculated plants. At this stage, only $\mathrm{crn} 2$ showed necrotic symptoms. A northern blot containing these samples was hybridized with probes of the tomato defense and pathogeninduced genes PR1a (van Kan et al. 1992) and hsr201 (Czernic et al. 1996), as well as a probe for the constitutive tomato gene tubulin. In contrast to the other treatments, PVX::crn2 treatment resembled pathogen infection and induced significant expression of both tomato defense-response genes PR1a and hsr201 (Fig. 9).

\section{DISCUSSION}

Single-pass cDNA sequencing is a relatively rapid and inexpensive procedure that has become a popular approach for large-scale gene discovery in eukaryotic plant pathogens, such as oomycetes, fungi, and nematodes (Kamoun et al. 1999b; Popeijus et al. 2000; Qutob et al. 2000; Dautova et al. 2001; Skinner et al. 2001). However, due to the inherent low quality and partial nature of single-pass cDNA sequences, gene annotation remains challenging, particularly the assignment of a putative function to sequences with no significant similarity to known genes. Here, we describe a general approach towards the identification of novel effector proteins from EST databases of eukaryotic plant pathogens by combining data mining for extracellular proteins with high-throughput functional expression assays in plants. This strategy led to the discovery of two novel necrosis- and defense responseinducing cDNAs, crn1 and crn2, that encode related extracellular proteins and that are members of a large, newly discovered gene family in Phytophthora.

We developed the algorithm PexFinder that scans ESTs for signal peptide sequences by integrating a series of scripts with SignalP, a program that distinguishes between cytoplasmic and extracellular oomycete proteins (Fig. 2B). We evaluated PexFinder performance by assigning a subcellular localization of the products of 55 of the Pex cDNAs based on functional annotation of their best matches and independently of SignalP scores (Suppl. Table S1). PexFinder's performance was satisfactory, as $73 \%$ of the examined cDNAs were similar to proteins known to be extracellular or membrane-associated in Phytophthora or in other organisms. However, some limitations of PexFinder and SignalP predictions were apparent. For example, some of the signal sequences identified in ESTs predicted to encode integral membrane proteins may correspond to internal transmembrane domains rather than $\mathrm{N}$-terminal secretory signal peptides. In addition, six cDNAs were predicted to encode mitochondrial proteins, suggesting that SignalP may not discriminate well between mitochondrial and secretory signal sequences. Future improvements in the SignalP program as well as the integration of additional steps to the algorithm should help address these limitations and further improve PexFinder's performance. Nevertheless, despite these limitations, PexFinder was validated convincingly using proteomic analyses of secreted proteins of $P$. infestans. A total of 22 different and randomly picked secreted proteins were fingerprinted using mass spectra of tryptic peptides. Of these, nine proteins (41\%) matched sequences in the selected set of 142 Pex cDNAs (Fig. 3; Suppl. Table S1). This may seem like a fairly high percentage considering that we only examined a relatively small number of ESTs. However, significant overlap between the two data sets is not surprising considering that both EST and proteomic analyses enrich for highly expressed genes and proteins.

Annotation of EST function is ordinarily done using similarity searches to sequences in public databases. Our results indicate that the PexFinder algorithm can help annotate those ESTs with no significant matches to known proteins, resulting in a manageable number of candidate genes that can then be tested using functional assays. The PVX expression system has emerged as a reliable and robust system for transient expression of genes in plant cells and has been widely used to express virulence and avirulence genes from plant pathogens (Hammond-Kosack et al. 1995; Kamoun et al. 1999a; Tobias et al. 1999; Tampakaki and Panopoulos 2000; Qutob et al. 2002). More recently, PVX has been successfully used to assay random cDNA clones from the fungal pathogen Cladosporium fulvum for HR-inducing activity (Takken et al. 2000). In the present study, we used the PVX expression system to assay 63 of the identified Pex cDNAs, including 54 
cDNAs of unknown function. We constructed agroinfectionready cDNA libraries by cloning pools of candidate full-length Pex cDNAs into the binary PVX vector, thus reducing the time required to handle a large number of cDNAs. An alternative approach would have been to screen random clones as performed by Takken et al. (2000). In fact, we conducted a similar screen with 2400 random cDNAs from $P$. infestans (A. Testa and S. Kamoun, unpubl.) and identified five necrosisinducing cDNAs. This suggests that selecting for candidate cDNAs using PexFinder resulted in a 15 -fold increase in identifying necrosis-inducing cDNAs $(2 / 63$ or $3 \%$ compared to $5 / 2400$ or $0.2 \%$ ). Preselecting Pex cDNAs also takes full advantage of existing genomic resources and avoids potential cloning biases against large transcripts. On the other hand, screening for random cDNAs is a hypothesis-free approach that has the potential of revealing effector molecules of an unexpected nature. In summary, we view both approaches as complementary strategies that can be equally pursued for the discovery of novel effector proteins from plant pathogens.

We selected to perform functional screenings in $N$. benthamiana, a plant species that is highly susceptible to PVX, is amenable to high-throughput PVX assays, and exhibits virusinduced gene silencing (VIGS) (Baulcombe 1999). In addition, $N$. benthamiana is known to display HR-based resistance responses to $P$. infestans and holds great promise for dissecting elicitor response and resistance to Phytophthora (Kamoun et al. 1998; Kamoun 2001). Using PVX expression assays in N. benthamiana, we discovered two novel necrosis-inducing cDNAs, crn1 and crn2, that encode related and novel extracellular elicitor proteins of Phytophthora. Recombinant PVX carrying the $\mathrm{crn}$ genes were compared in side-by-side inoculations to PVX constructs expressing the HR-elicitor inf1 elicitin gene of $P$. infestans (Kamoun et al. 1998, 1999b), and the defense and necrosis-inducing gene PsojNIP of P. sojae (Qutob et al. 2002). Overall, the responses induced by the $\mathrm{crn}$ genes differed from those induced by inf1 and PsojNIP. First, necrotic symptoms were delayed compared to the other two elicitors, and occurred 1-2 d later for $\mathrm{crn} 2$ and $\sim 7 \mathrm{~d}$ later for $\mathrm{crn} 1$ (Fig. 8). The exact significance of this difference is unclear at this stage but could be due to a lower specific activity for the CRN products, thus requiring more virus accumulation before an effective concentration is reached. The appearance of the necrotic lesions also varied between the $\mathrm{crn}$ genes and the inf1 and PsojNIP genes. Both INF1 and PsojNIP induced dark black lesions in Nicotiana, whereas CRN1 and CRN2 induced light brown lesions that later developed dark black edges. This difference could reflect the induction of secondary metabolite pathways by CRNs that vary from those induced by the other elicitors. However, the ability of CRN2 to induce defense- and pathogenesis-related genes was reminiscent of INF1 and other elicitors. In tobacco, similar to INF1, the necrosis induced by CRN2 was associated with the activation of the tobacco defense-response gene PR2 (data not shown). In tomato, CRN2 induced the defense genes PR1a and hsr201 (Fig. 9) that are known to be up-regulated during infection by microbial pathogens. In this respect, CRN2 appeared to mimic pathogen infection of tomato. In summary, it appears that CRN2 induces defense responses in plants similar to those induced by known defense elicitors, but with different timing and appearance of the necrotic response. This indicates that CRNs may induce defense pathways in plants different from those induced by INF1 and PsojNIP. The crn genes may thus be useful in helping dissect plant defense pathways. Future work will include extensive studies of plant responses to CRN
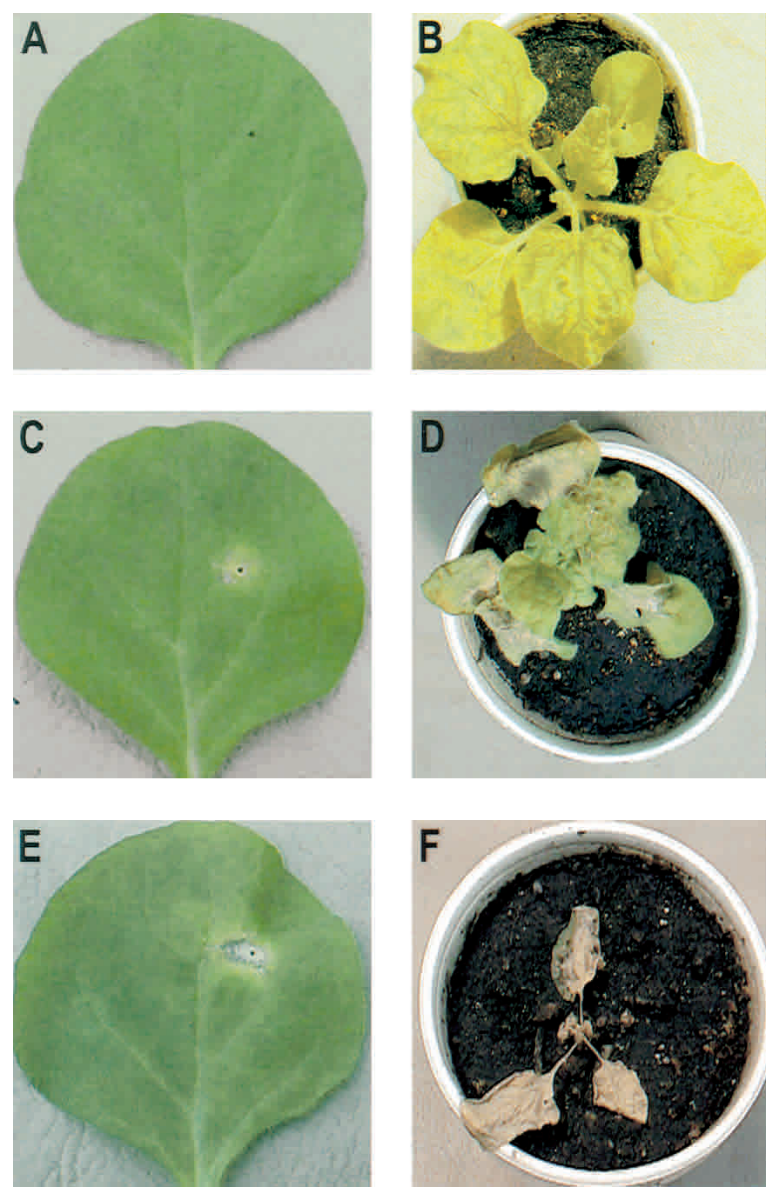

Figure 5 Symptoms observed on $N$. benthamiana plants after inoculation with $A$. tumefaciens containing the binary PVX vector expressing $P$. infestans $\mathrm{crn} 1$ and $\mathrm{crn} 2 \mathrm{CDNAs}$. Inoculated leaves and plantlets of $N$. benthamiana were photographed $12(A, C, E)$ or 16 $(B, D, F) \mathrm{d}$ after inoculation with $A$. tumefaciens containing the binary PVX vector pGR106 (Jones et al. 1999) $(A, B)$, pGR106 derivative expressing $c r n 1$ cDNA $(C, D)$, or pGR106 derivative expressing $c r n 2$ CDNA $(E, F)$. Panels $B, D$, and $E$ correspond to an independent experiment from panels $A, C$, and $F$, in which smaller plants were inoculated, resulting in faster systemic spread of the virus. Panels $A, B$ show no symptoms at the inoculation site and systemic mosaic symptoms typical of PVX infection. Panels C-E show localized necrosis at site of inoculations, and panels $D-F$ show systemic necrotic symptoms. Note that the symptoms obtained with the $c r n 2$ construct were observed as early as $5 \mathrm{~d}$ after inoculation, and the symptoms induced by $\mathrm{crn} 1$ occurred later, starting around $12 \mathrm{~d}$ after inoculation.

and identification of plant mutants deficient in CRN response.

Molecular characterization of the $\mathrm{crn}$ genes suggests that they are widely distributed and form a complex gene family in Phytophthora similar to the ubiquitous INF elicitin family (Kamoun et al. 1997; Kamoun 2000). However, the predicted CRN proteins are structurally unrelated to INF elicitins. The large size ( $~ 450$ amino acids) of CRN1 and CRN2, the lack of notable features in the CRN primary structures, and the presence of CRN conserved motifs suggest that these proteins may function as secreted enzymes similar to the $42-\mathrm{kD}$ glycoprotein elicitor of $P$. sojae (Sacks et al. 1995), which was recently found to possess transglutaminase activity ( $T$. Nürnberger, pers. comm.). No similarity was also noted to the recently

\section{Genome Research}




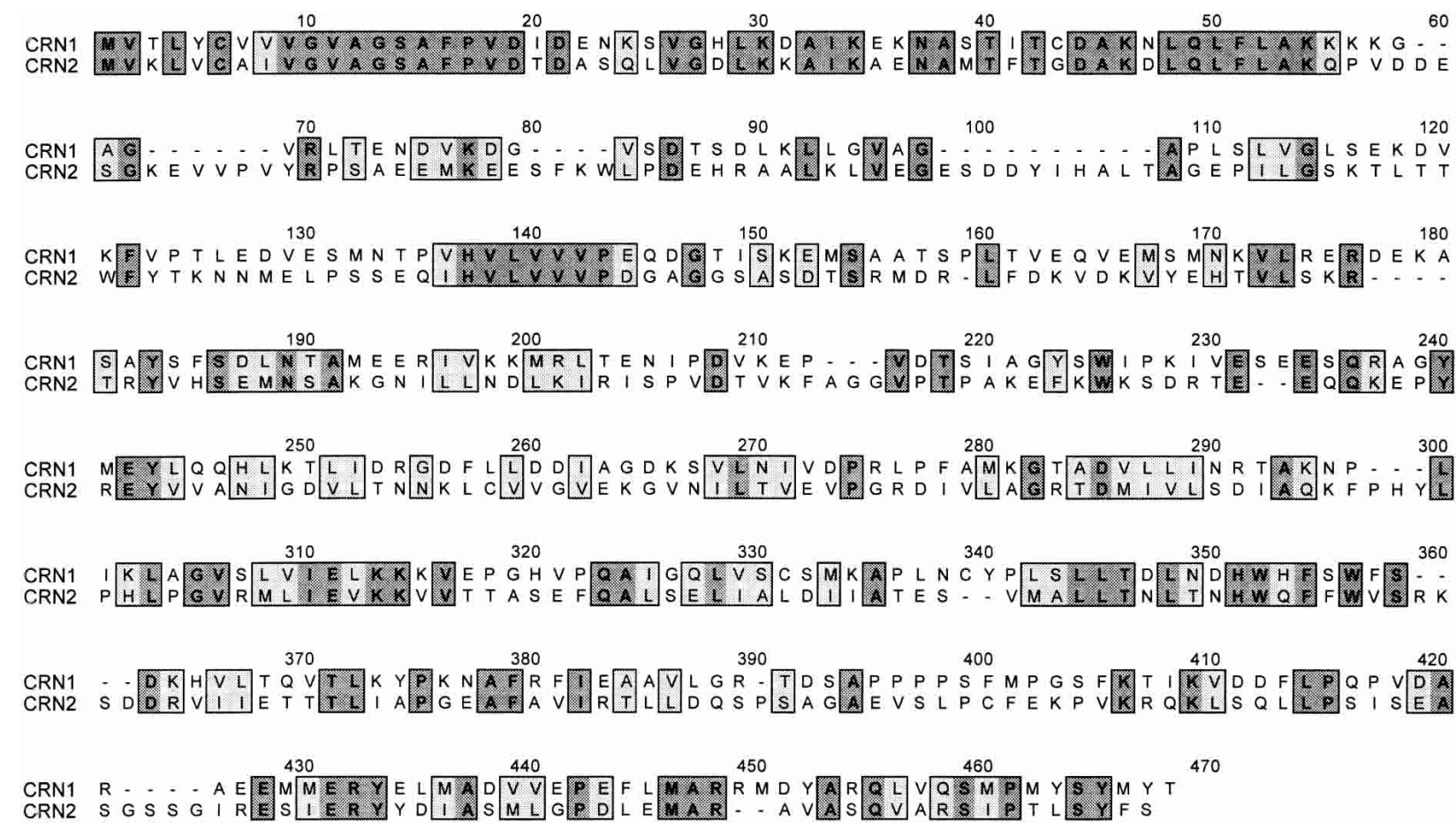

Figure 6 Alignment of $P$. infestans CRN1 and CRN2 predicted amino acid sequences. The amino acid sequences of CRN1 and CRN2 were predicted from full ORF sequences. Identical amino acids are shaded in dark gray and similar ones in light gray. The predicted mature CRN1 protein starts at position 18 (VDI...), and the mature CRN2 protein at position 23 (SQL...). A multiple alignment of all known CRN-like sequences is available as a Web Supplement.

characterized necrosis-inducing protein PsojNIP of $P$. sojae (Qutob et al. 2002). However, unlike the inf1 and PsojNIP genes, which were reported to be down-regulated in the early stages of infection, the crn genes appeared to be constitutively expressed both in planta and in vitro. The observation that the $c r n$ genes are expressed in $P$. infestans during colonization of tomato (Fig. 7) suggests that the CRN products could be secreted and thus delivered to plant cells during infection.

Analyses of the response induced by the $\mathrm{crn}$ cDNAs in various plants suggest that they are general elicitors that trigger necrotic responses nonspecifically in both resistant Nicotiana species and the susceptible host plant tomato. In this respect, the CRNs differ from specific elicitors, such as INF1, which induce defense responses only in specific plant genotypes (Kamoun et al. 1998, 1999a), but resemble PsojNIP, which functions in several dicotyledonous plants (Qutob et al. 2002). The general elicitors of plant pathogens were recently likened to pathogen-associated molecular patterns (PAMPs), which are surface-derived molecules that induce the expression of defense-response genes and the production of antimicrobial compounds in both animal and plant cells (Gomez-Gomez and Boller 2002; Nürnberger and Brunner 2002). Whether the CRN proteins function as PAMPs remains to be determined, but is supported by the observation that the crn genes were found in several Phytophthora species. Alternatively, the CRNs could be aiding in colonization of plant tissue during the late necrotrophic phase of infection, as proposed for the PsojNIP protein (Qutob et al. 2002). In the future, additional functional analyses of the $\mathrm{crn}$ genes in $P$. infestans and other Phytophthora species will help determine the nature of the contribution of these genes to the infection process.

In principle, the two-step functional genomics strategy we developed can be applied to a variety of eukaryotic plant pathogens, including fungi and nematodes. Preliminary analyses of PexFinder-processed ESTs from plant parasitic nematodes suggest that the algorithm performs well in that system (T. Maier and T. Baum, pers. comm.). In the future, accumulation of ESTs from plant pathogens and further improvements in virus vector technology should allow a broad application of this strategy to the study of plant-microbe interactions.

\section{METHODS}

\section{PexFinder Program}

PexFinder was written as a series of programs/scripts in $\mathrm{C}++$ and Perl using a Linux platform. The program runs in conjunction with SignalP v2.0b2 as available on the Web (http:// www.cbs.dtu.dk/services/SignalP-2.0) or as a stand-alone application. The programs as well as detailed instructions for use can be downloaded from http://www.oardc.ohio-state.edu/ phytophthora/pexfinder.

\section{Data Sets}

The processed ESTs (GenBank accession nos. BE775444BE777460) were generated as $5^{\prime}$ reads of random clones picked from a cDNA library constructed from mycelial RNA of $P$. infestans (Kamoun et al. 1999b). A control data set of annotated sequences corresponding to 59 oomycete genes (Suppl. Table S2) was compiled from GenBank (23 sequences) and the Phytophthora Genome Initiative (PGI) database (36 


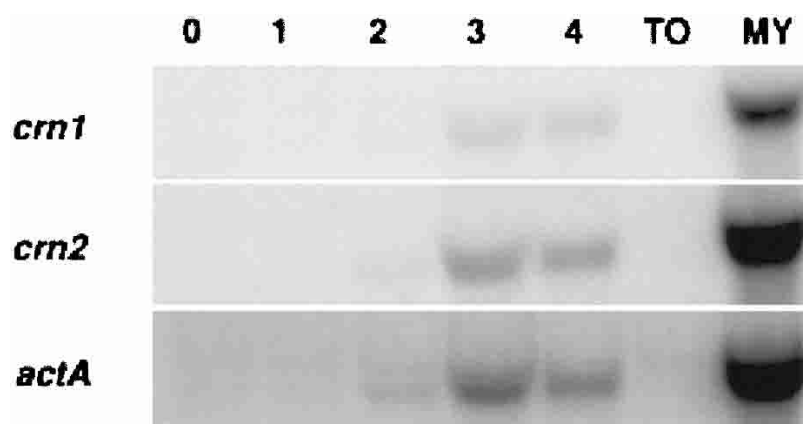

Figure 7 Time course of expression of $c r n 1, \mathrm{crn} 2$ and act $A$ of $P$. infestans during colonization of tomato. Total RNA isolated from infected leaves of tomato, $0,1,2,3$, or $4 \mathrm{~d}$ after inoculation, from noninfected leaves (TO), and from $P$. infestans mycelium grown in synthetic medium (MY) was sequentially hybridized with probes from the $c r n 1, c r n 2$, and actA genes. The approximate sizes of the transcripts are $\sim 1700$ nucleotides for $c r n 1$ and $c r n 2$, and $~ 1600$ nucleotides for actA.

sequences; Waugh et al. 2000). The 36 full-length cDNAs were selected from a list of nonredundant ESTs with highly significant matches (E values $<10^{-30}$ ) to known proteins (Kamoun et al. 1999b). The inserts of these cDNAs were fully sequenced using a primer walking approach and deposited in GenBank (see Suppl. Table S2 for accession nos.). Subcellular localizations were determined based on information obtained from the InterPro collection of databases of protein families, domains, and functional sites (Apweiler et al. 2001), GenBank (Karsch-Mizrachi and Ouellette 2001), or was based on literature review of the examined protein.

\section{Strains and Culture Conditions}

The ESTs were obtained from $P$. infestans strain isolate DDR7602 (US-1 genotype, A1 mating type). This isolate is avirulent on $N$. benthamiana. P. infestans isolate 90128 (A2 mating type, race 1.3.4.7.8.9.10.11) was used in the infection assay. The isolates were routinely grown on rye agar medium supplemented with $2 \%$ sucrose (Caten and Jinks 1968). For RNA extraction, plugs of mycelium were transferred to modified Plich medium (Kamoun et al. 1993) and grown for 2-3 wks before harvesting. For proteomics, the synthetic medium of Henniger (1959) was used.

A. tumefaciens strain GV3101 (Holsters et al. 1980) was used in molecular cloning experiments and was routinely grown at $28^{\circ} \mathrm{C}$ in Luria-Bertani (LB) media using the appropriate antibiotics (Sambrook et al. 1989). Prior to storage at $-80^{\circ} \mathrm{C}$, cultures were grown without shaking in microplates containing $60 \mu \mathrm{L} \mathrm{LB}$ freezing buffer $\left(36 \mathrm{mM} \mathrm{K}_{2} \mathrm{HPO}_{4}, 13.2\right.$ $\mathrm{mM} \mathrm{K} \mathrm{HPO}_{4}, 1.7 \mathrm{mM}$ citrate, $0.4 \mathrm{mM} \mathrm{MgSO}_{4}, 6.8 \mathrm{mM}$ $\left(\mathrm{NH}_{4}\right)_{2} \mathrm{SO}_{4}, 4.4 \% \mathrm{v} / \mathrm{v}$ glycerol in $\left.1 \times \mathrm{LB}\right)$.

\section{Proteomic Analysis of Secreted Proteins}

We cultured $P$. infestans in the synthetic medium of Henniger (1959). Seven to ten d after inoculation, culture filtrate was collected. Care was taken to keep mycelia untouched. A 0.2$\mu \mathrm{m}$ filter (Sartorius) was used to remove any loose cell debris before the collections were stored at $-20^{\circ} \mathrm{C}$. For protein precipitation, we added acetone to the culture filtrates up to $60 \%$ $(\mathrm{v} / \mathrm{v})$ and kept the solution at $-20^{\circ} \mathrm{C}$ for $1 \mathrm{~h}$ to reduce the amount of INF1, an abundantly secreted protein in $P$. infestans (Kamoun et al. 1998). A protein pellet was obtained by centrifugation $(10,000 \mathrm{rpm}, 10 \mathrm{~min})$ and air-dried at room temperature before storage at $-20^{\circ} \mathrm{C}$. Protein samples were dissolved in 2-D lysis buffer (0.01 M Tris-HCl, pH 7.4, $1 \mathrm{mM}$ EDTA, $8 \mathrm{M}$ urea, $0.05 \mathrm{M}$ DTT, 10\% [v/v] glycerol, 5\% [v/v] CHAPS, and 6\% [w/v] ampholytes [Resolyte $\mathrm{pH} 3-10])$ and kept at $-70^{\circ} \mathrm{C}$. Up to $60 \mu \mathrm{L}$ of protein sample was run on a 7-cm pH 3-10 nonlinear pH gradient strip (IPG; AmershamPharmacia Biotech.) and run as described by Martin et al. (2001). For the second-dimension electrophoresis, a mini 2-D gel system was employed using the protocol described by Martin et al. (2001). Proteins were visualized by colloidal Coomassie Brilliant Blue G-250 staining as described by Cash et al. (1997), or silver-stained using the Plus-One Protein staining kit from Amersham Biosciences, according to the manufacturer's instructions. Molecular masses of the proteins were determined by co-electrophoresis with standard protein markers. Iso-electric points were determined based on the linearity of the IPG strip. Peptide-mass mapping was conducted on several protein spots from the Coomassie-stained gels. Excised proteins were in-gel-digested with trypsin (sequencinggrade modified trypsin; Promega) and prepared as described by Shevchenko et al. (1996) and Wilm et al. (1996). Mass spectra were acquired on a PerSeptive Biosystems Voyager-DE STR MALDI-TOF mass spectrometer. The masses of the tryptic fragments were entered into the MS-Fit program (MS-Fit 3.1.1, Protein Prospector 3.2.1, University of California) to search the Pex cDNA sequences for protein identification. Search parameters were as follows: maximum peptide mass tolerance was 200ppm; cysteines were modified by carbamidomethylation; maximum allowed missed cleavages were 2 .

\section{Construction of cDNA Mini-Libraries}

A mini-library of the 63 cDNAs was constructed in the binary potato virus X (PVX vector) pGR106 (Jones et al. 1999; http:// www.jic.bbsrc.ac.uk/Sainsbury-Lab/david-baulcombe/ Services/vigsprotocol.htm) as follows. The $63 \mathrm{cDNA}$ inserts were PCR-amplified using high-fidelity $p f u$ DNA polymerase (Strategene) and the primers PSPORT-ASC (5'-GGCCGG

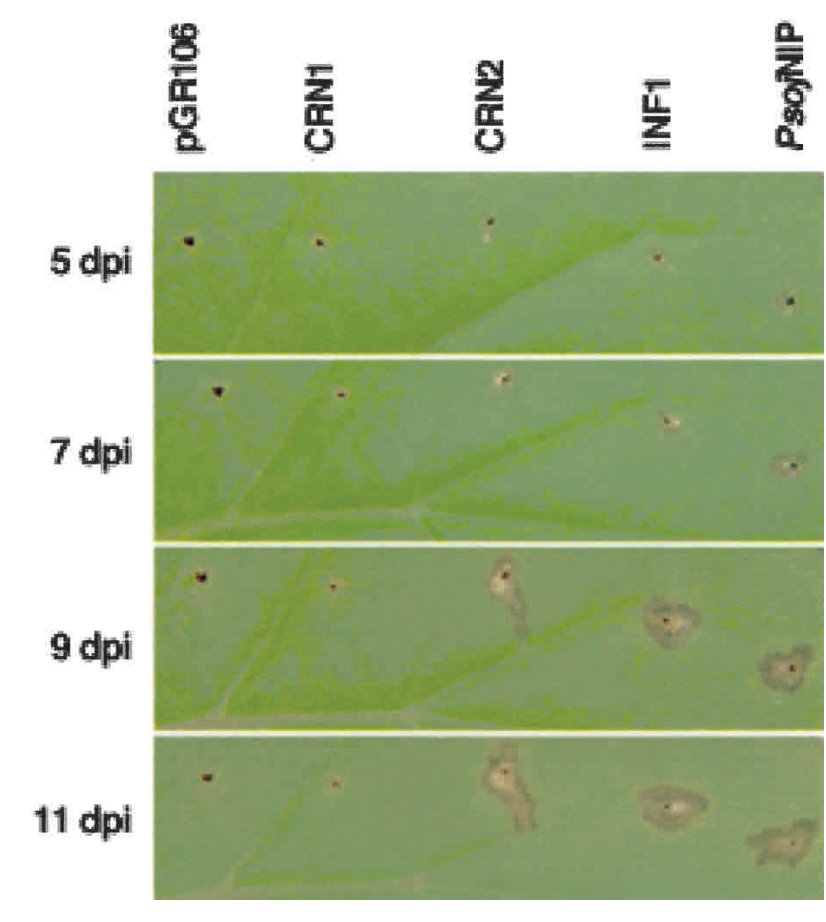

Figure 8 Symptoms observed on $N$. benthamiana plants after inoculation with $A$. tumefaciens containing binary PVX derivatives expressing $c r n 1, c r n 2$, and inf1 from $P$. infestans or PsojNIP from $P$. sojae. Side-by-side toothpick inoculations were performed on leaves of 5 -wk-old N. benthamiana. The binary PVX vector pGR106 was used as a negative control. Photographs were taken 5, 7, 9, and $11 \mathrm{~d}$ postinoculation (dpi).

\section{Genome Research




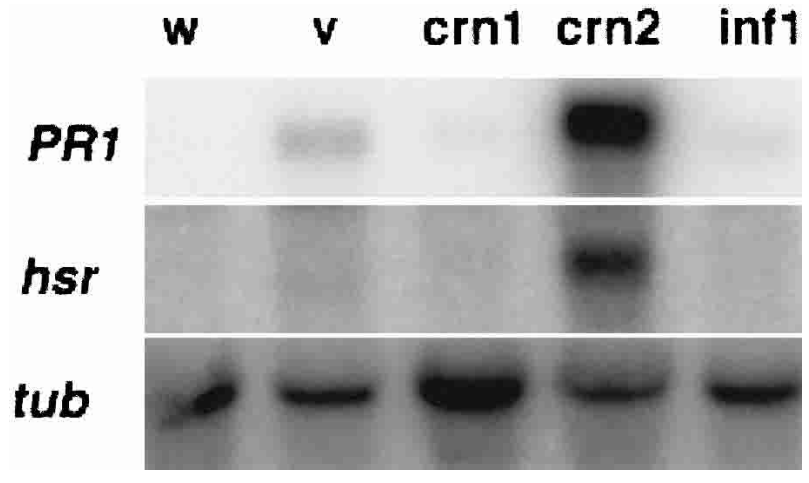

Figure 9 Induction of tomato defense genes by $\mathrm{crn}$ genes. Total RNA $(15 \mu \mathrm{g})$ isolated from tomato $12 \mathrm{~d}$ after mock inoculation with a toothpick (W), or with the binary potato virus X pGR106 (V), PVX:: crn1 (crn1), PVX::crn2 (crn2), and PVX:: inf1 was sequentially hybridized with probes from the tomato PR1 $a$ and $h s r 201$ defense-response genes. A probe from the tomato tubulin $(t u b)$ gene was used as a loading control. Note in tomato and under these experimental conditions, only PVX::crn2 induced necrotic lesions.

CGCGCCCTCCCGGGTCGACCCACGCGTCC-3') and SP6 (5'-TACGATTTAGGTGACACTATAG-3'), which correspond to vector sequences. The approximate size of the cDNA inserts was estimated using gel electrophoresis, and the 63 cDNAs were divided into eight pools of 4-10 clones based on fragment size. Following pooling, the cDNAs were digested with AscI and NotI, ligated to pGR106, and electroporated into $A$. tumefaciens GV3101 to generate an agroinfection-ready minilibrary of $\sim 760$ clones, with each pool represented by at least an eightfold coverage.

\section{Plant Assays}

Young $N$. benthamiana plants at approximately the 3-4-leaf stage ( $\sim 3$-wk-old) were used for the agroinfection screening assays. Plants were cultured and maintained in a greenhouse with an ambient temperature of $22^{\circ}-25^{\circ} \mathrm{C}$ and high light intensity. Under these conditions, plants grew vigorously, which resulted in rapid PVX infection. Inoculations were performed on two lower leaves by dipping a wooden sterile toothpick in a recombinant A. tumefaciens GV3101 (PVX:: cDNA) culture grown on solid agar medium and then wounding each leaf twice around the main vein and near the base of the leaf. An excess of bacteria was used for the inoculations. Mosaic, crinkling, and local and systemic necrotic symptoms were scored daily and typically started developing within 5-7 $\mathrm{d}$ after inoculation. Inserts of clones of interest were PCRamplified with PVX primers PVX-F (5'- AATCAATCACAGT GTTGGCTTGC-3') and PVX-R (5'- AGTTGACCCTATGGGCT GTGTTG-3') and sequenced using the same primers. PVX:: cDNA constructs that induced necrotic symptoms were retested at least five times on 3-4 leaf plants and also in sideby-side inoculation on older plants with more than six leaves to allow comparative analyses. Tomato and tobacco plants were inoculated using similar methods.

For the time-course northern blot of $P$. infestans colonization of tomato, fully expanded tomato leaves were detached and inoculated as described earlier (Kamoun et al. 1998). A $10-\mu \mathrm{L}$ sample containing $\sim 1000$ zoospores of $P$. infestans was used to inoculate the underside of the detached leaves. Leaf discs of similar sizes were dissected from the inoculated regions while making sure that the inoculation spot is in the center. The leaf disks were frozen in liquid nitrogen and stored at $-80^{\circ} \mathrm{C}$ for later use.

For the northern blot experiment on plant defense responses, cotyledons of young tomato plants with fully ex- panded leaves were toothpick-inoculated with the PVX derivatives. Leaves were harvested from systemically infected leaves $12 \mathrm{~d}$ postinoculation, frozen in liquid nitrogen, and stored at $-80^{\circ} \mathrm{C}$ for later use.

\section{DNA Manipulations, Sequencing, and} Sequence Analysis

DNA manipulations were conducted essentially as described elsewhere (Sambrook et al. 1989). cDNAs were sequenced by primer walking using an ABI Prism 377 automated sequencer (PE Applied Biosystems). Similarity searches were performed locally on an Intel Linux workstation using BLAST (Altschul et al. 1997). Local databases included GenBank nonredundant and dBEST (Karsch-Mizrachi and Ouellette 2001), PGI (Waugh et al. 2000), and SPC, a proprietary database of Syngenta Inc. containing $\sim 34,000$ ESTs from $P$. infestans (courtesy of S. Lam, Syngenta). Multiple alignment of the $c r n$-like sequences from $P$. infestans, $P$. sojae, and $P$. medicaginis was conducted using the program CLUSTAL-X (Thompson et al. 1997).

\section{Northern Blot Hybridizations}

Total RNA from P. infestans mycelium and from infected tomato leaves was isolated using the Trizol reagent (Gibco-BRL) following the manufacturer's instructions. To prepare the northern blot, $15 \mu \mathrm{g}$ RNA was denatured in NorthernMax Gel Loading Solution (Glyoxal; Ambion) according to the manufacturer's instructions. RNA was separated by gel electrophoresis on a $1 \%$ agarose gel in $1 \times$ BPTE buffer $(10 \mathrm{mM}$ PIPESpiperazine- $N, N^{\prime}$-bis[ethanesulfonic acid], $30 \mathrm{mM}$ Bis-Tris, 1 mM EDTA pH 8.0; Sambrook et al. 1989). Transfer was done onto Hybond $\mathrm{N}^{+}$membrane (Amersham) as described by the manufacturer. Hybridizations were done with radiolabeled probes at $65^{\circ} \mathrm{C}$ in Modified Church Buffer $\left(0.36 \mathrm{M} \mathrm{Na}_{2} \mathrm{HPO}_{4}\right.$, $0.14 \mathrm{NaH}_{2} \mathrm{PO}_{4}, 1 \mathrm{mM}$ EDTA, and 7\% SDS). Membranes were washed at $55^{\circ} \mathrm{C}$ for $15 \mathrm{~min}$ each in $1 \times \mathrm{SSC} / 0.5 \%$ SDS and $0.5 \times$ SSC $/ 0.5 \%$ SDS. Membranes with RNA side up were exposed to a phosphor imager screen (Molecular Dynamics Storm 840 Phosphor Imager) for 2-48 h.

Probes for the crn and actin genes were gel-purified fragments digested from the corresponding cDNA clones (this study; Unkles et al. 1991). Probes for the tomato genes were gel-purified DNA fragments obtained from cDNA clones (E. Huitema and S. Kamoun, unpubl.) and corresponded to the PR1a gene (van Kan et al. 1992), the hsr201 gene (Czernic et al. 1996), and tubulin (GenBank accession CAD13178). All probes were radiolabeled with $\alpha-{ }^{32} \mathrm{P}-\mathrm{dATP}$ using a random primer labeling kit (Gibco-BRL).

\section{ACKNOWLEDGMENTS}

We thank Caitlin Cardina, Shujing Dong, and Diane Kinney for expert technical assistance, Ian Holford, Peter Hraber, and Callum Bell for help with programming, Jesse Ewing for help with figure design, Abdelhafid Bendahmane for the recipe of the LB freezing medium, and Isabelle Malcuit and David Baulcombe for providing pGR106 and help with the PVX system. We also thank Tea Meulia and the staff of the OARDC Molecular and Cellular Imaging Center for help with DNA sequencing, and the following members of the Aberdeen Proteome Facility, Scotland UK: Phil Cash, Evelyn Argo, and Audrey Innes for running the 2-D gels, and Liz Stewart and Ian Davidson for mass spectrometry analysis. This work was supported by the OARDC Research Enhancement Grant Program, Syngenta Biotechnology, and NSF grant DBI-0211659 to S.K. P.v.W. was supported by the Royal Society. Salaries and research support were provided, in part, by State and Federal Funds appropriated to the Ohio Agricultural Research and Development Center, The Ohio State University.

The publication costs of this article were defrayed in part by payment of page charges. This article must therefore be 
hereby marked "advertisement" in accordance with 18 USC section 1734 solely to indicate this fact.

\section{REFERENCES}

Altschul, S.F., Madden, T.L., Schaffer, A.A., Zhang, J., Zhang, Z., Miller, W., and Lipman, D.J. 1997. Gapped BLAST and PSI-BLAST: A new generation of protein database search programs. Nucleic Acids Res. 17: 3389-3402.

Apweiler, R., Attwood, T.K., Bairoch, A., Bateman, A., Birney, E., Biswas, M., Bucher, P., Cerutti, L., Corpet, F., Croning, M.D., et al. 2001. The InterPro database, an integrated documentation resource for protein families, domains and functional sites. Nucleic Acids Res. 29: 37-40.

Baker, B., Zambryski, P., Staskawicz, B., and Dinesh-Kumar, S.P. 1997. Signaling in plant-microbe interactions. Science 276: $726-733$.

Baulcombe, D.C. 1999. Fast forward genetics based on virus-induced gene silencing. Curr. Opin. Plant Biol. 2: 109-113.

Cash, P., Argo, E., Langford, P.R., and Kroll, J.S. 1997. Development of a Haemophilus two-dimensional protein database. Electrophoresis 18: 1472-1482.

Caten, C.E. and Jinks, J.L. 1968. Spontaneous variability of single isolates of Phytophthora infestans. I. Cultural variation. Can. J. Bot. 46: 329-347.

Collmer, A., Badel, J.L., Charkowski, A.O., Deng, W.L., Fouts, D.E., Ramos, A.R., Rehm, A.H., Anderson, D.M., Schneewind, O., van Dijk, K., et al. 2000. Pseudomonas syringae Hrp type III secretion system and effector proteins. Proc. Natl. Acad. Sci. 97: 8770-8777.

Czernic, P., Huang, H.C., and Marco, Y. 1996. Characterization of $h s r 201$ and $h s r 515$, two tobacco genes preferentially expressed during the hypersensitive reaction provoked by phytopathogenic bacteria. Plant Mol. Biol. 31: 255-265.

Dautova, M., Rosso, M., Abad, P., Gommers, F.J., Bakker, J., and Smant, G. 2001. Single pass cDNA sequencing-A powerful tool to analyze gene expression in preparasitic juveniles of the southern root-knot nematode Meloidogyne incognita. Nematology 3: $129-139$.

Fry, W.E. and Goodwin, S.B. 1997a. Re-emergence of potato and tomato late blight in the United States. Plant Dis. 81: 1349-1357. . 1997b. Resurgence of the Irish potato famine fungus. Bioscience 47: 363-371.

Gomez-Gomez, L. and Boller, T. 2002. Flagellin perception: A paradigm for innate immunity. Trends Plant Sci. 6: 251-256.

Hahn, M. and Mendgen, K. 2001. Signal and nutrient exchange at biotrophic plant-fungus interfaces. Curr. Opin. Plant Biol. 4: $322-327$.

Hammond-Kosack, K.E., Staskawicz, B.J., Jones, J.D.G., and Baulcombe, D.C. 1995. Functional expression of a fungal avirulence gene from a modified potato virus X genome. Mol. Plant-Microbe Interact. 8: 181-185.

Henniger, H. 1959. Versuche zur Kultur verscheidener Rassen von Phytophthora infestans (Mont.) de Bary auf Künstlichen Nahrboden. Phytopathol. Z. 34: 285-306.

Holsters, M., Silva, B., Van Vliet, F., Genetello, C., De Block, M., Dhaese, P., Depicker, A., Inze, D., Engler, G., Villaroel, R., et al. 1980. The functional organization of the nopaline A. tumefaciens plasmid pTiC58. Plasmid 3: 212-230.

Jia, Y., McAdams, S.A., Bryan, G.T., Hershey, H.P., and Valent, B. 2000. Direct interaction of resistance gene and avirulence gene products confers rice blast resistance. EMBO J. 19: 4004-4014.

Jones, L., Hamilton, A.J., Voinnet, O., Thomas, C.L., Maule, A.J., and Baulcombe, D.C. 1999. RNA-DNA interactions and DNA methylation in posttranscriptional gene silencing. Plant Cell 11: 2291-2301.

Kamoun, S. 2000. Phytophthora. In Fungal pathology (ed. J. Kronstad), pp. 237-265. Kluwer Academic Publishers, The Netherlands.

Kamoun, S. 2001. Nonhost resistance to Phytophthora: Novel prospects for a classical problem. Curr. Opin. Plant Biol. 4: 295-300.

Kamoun, S., Honee, G., Weide, R., Lauge, R., Kooman-Gersmann, M., de Groot, K., Govers, F., and de Wit, P.J.G.M. 1999a. The fungal gene Avr9 and the oomycete gene inf1 confer avirulence to potato virus X on tobacco. Mol. Plant-Microbe Interact. 12: $459-462$

Kamoun, S., Hraber, P., Sobral, B., Nuss, D., and Govers, F. 1999b. Initial assessment of gene diversity for the oomycete pathogen Phytophthora infestans based on expressed sequences. Fungal Genet. Biol. 28: 94-106.
Kamoun, S., Lindqvist, H., and Govers, F. 1997. A novel class of elicitin-like genes from Phytophthora infestans. Mol. Plant-Microbe Interact. 10: 1028-1030.

Kamoun, S., van West, P., Vleeshouwers, V.G., de Groot, K.E., and Govers, F. 1998. Resistance of Nicotiana benthamiana to Phytophthora infestans is mediated by the recognition of the elicitor protein INF1. Plant Cell 10: 1413-1426.

Kamoun, S., Young, M., Glascock, C., and Tyler, B.M. 1993. Extracellular protein elicitors from Phytophthora: Host-specificity and induction of resistance to fungal and bacterial phytopathogens. Mol. Plant-Microbe Interact. 6: 15-25.

Karsch-Mizrachi, I. and Ouellette, B.F. 2001. The GenBank sequence database. Methods Biochem. Anal. 43: 45-63.

Kjemtrup, S., Nimchuk, Z., and Dangl, J.L. 2000. Effector proteins of phytopathogenic bacteria: Bifunctional signals in virulence and host recognition. Curr. Opin. Microbiol. 3: 73-78.

Klein, R.D., Gu, Q., Goddard, A., and Rosenthal, A. 1996. Selection for genes encoding secreted proteins and receptors. Proc. Natl. Acad. Sci. 93: 7108-7113.

Knogge, W. 1996. Fungal infections of plants. Plant Cell 8: $1711-1722$

Lauge, R. and De Wit, P.J. 1998. Fungal avirulence genes: Structure and possible functions. Fungal Genet. Biol. 24: 285-297.

Long, S., McCune, S., and Walker, G.C. 1988. Symbiotic loci of Rhizobium meliloti identified by random TnphoA mutagenesis. J. Bacteriol. 170: 4257-4265.

Martin, S.A.M., Cash, P., Blaney, S., and Houlihan, D.F. 2001. Proteome analysis of rainbow trout (Oncorhynchus mykiss) liver proteins during short term starvation. Fish Physiol. Biochem. 24: $259-270$.

Menne, K.M., Hermjakob, H., and Apweiler, R. 2000. A comparison of signal sequence prediction methods using a test set of signal peptides. Bioinformatics 16: 741-742.

Nürnberger, T. and Brunner, F. 2002. Innate immunity in plants and animals: Emerging parallels between the recognition of general elicitors and pathogen-associated molecular patterns. Curr. Opin. Plant Biol. 4: 318-324.

Nielsen, H., Engelbrecht, J., Brunak, S., and von Heijne, G. 1997. Identification of prokaryotic and eukaryotic signal peptides and prediction of their cleavage sites. Protein Eng. 10: 1-6.

Nielsen, H. and Krogh, A. 1998. Prediction of signal peptides and signal anchors by a hidden Markov model. In Proceedings of the Sixth International Conference on Intelligent Systems for Molecular Biology (ISMB 6), pp. 122-130. AAAI Press, Menlo Park, CA.

Parniske, M. 2000. Intracellular accommodation of microbes by plants: A common developmental program for symbiosis and disease? Curr. Opin. Plant Biol. 3: 320-328.

Pearson, W.R. 1990. Rapid and sensitive sequence comparison with FASTP and FASTA. Methods Enzymol. 183: 63-98.

Popeijus, M., Blok, V.C., Cardle, L., Bakker, E., Phillips, M.S., Helder, J., Smant, G., and Jones, J.T. 2000. Analysis of genes expressed in second stage juveniles of the potato cyst nematodes Globodera rostochiensis and G. pallida using the expressed sequence tag approach. Nematology 2: 567-574.

Qutob, D., Hraber, P.T., Sobral, B.W., and Gijzen, M. 2000. Comparative analysis of expressed sequences in Phytophthora sojae. Plant Physiol. 123: 243-254.

Qutob, D., Kamoun, S., and Gijzen, M. 2002. Expression of a Phytophthora sojae necrosis-inducing protein occurs during transition from biotrophy to necrotrophy. Plant J. 32: 361-373.

Rapoport, T.A. 1992. Transport of proteins across the endoplasmic reticulum membrane. Science 258: 931-936.

Sacks, W., Nurnberger, T., Hahlbrock, K., and Scheel, D. 1995. Molecular characterization of nucleotide sequences encoding the extracellular glycoprotein elicitor from Phytophthora megasperma. Mol. Gen. Genet. 246: 45-55.

Sambrook, J., Fritsch, E.F., and Maniatis, T. 1989. Molecular cloning: A laboratory manual, 2nd ed. Cold Spring Harbor Laboratory Press, Cold Spring Harbor, NY.

Shevchenko, A., Wilm, M., Vorm, O., and Mann, M. 1996. Mass spectrometric sequencing of proteins from silver stained polyacrylamide gels. Anal. Chem. 68: 850-858.

Skinner, W., Keon, J., and Hargreaves, J. 2001. Gene information for fungal plant pathogens from expressed sequences. Curr. Opin. Microbiol. 4: $381-386$.

Staskawicz, B.J., Mudgett, M.B., Dangl, J.L., and Galan, J.E. 2001. Common and contrasting themes of plant and animal diseases. Science 292: 2285-2289.

Takken, F.L., Luderer, R., Gabriels, S.H., Westerink, N., Lu, R., De Wit, P.J., and Joosten, M.H. 2000. A functional cloning strategy,

\section{Genome Research}


based on a binary PVX-expression vector, to isolate HR-inducing cDNAs of plant pathogens. Plant J. 24: 275-283.

Tampakaki, A.K. and Panopoulos, N.J. 2000. Elicitation of hypersensitive cell death by extracellularly targeted HrpZ_Psph produced in plant. Mol. Plant-Microbe Interact. 13: 1366-1374

Templeton, M.D., Rikkerink, E.H.A., and Beever, R.E. 1994. Smal cysteine-rich proteins and recognition in fungal-plant interactions. Mol. Plant-Microbe Interact. 7: 320-325.

Thompson, J.D., Gibson, T.J., Plewniak, F., Jeanmougin, F., and Higgins, D.G. 1997. The CLUSTAL_X windows interface: Flexible strategies for multiple sequence alignment aided by quality analysis tools. Nucleic Acids Res. 25: 4876-4882.

Tobias, C.M., Oldroyd, G.E., Chang, J.H., and Staskawicz, B.J. 1999. Plants expressing the Pto disease resistance gene confer resistance to recombinant PVX containing the avirulence gene AvrPto. Plant I. 17: 41-50.

Unkles, S.E., Moon, R.P., Hawkins, A.R., Duncan, J.M., and Kinghorn, J.R. 1991. Actin in the oomycetous fungus Phytophthora infestans is the product of several genes. Gene 100: $105-112$.

van Kan, J.A., Joosten, M.H., Wagemakers, C.A., van den Berg-Velthuis, G.C., and de Wit, P.J. 1992. Differential accumulation of mRNAs encoding extracellular and intracellular $\mathrm{PR}$ proteins in tomato induced by virulent and avirulent races of Cladosporium fulvum. Plant Mol. Biol. 20: 513-527.

von Heijne, G. 1985. Signal sequences. The limits of variation. J. Mol. Biol. 184: 99-105.

Wang, X., Allen, R., Ding, X., Goellner, M., Maier, T., de Boer, J.M.,
Baum, T.J., Hussey, R.S., and Davis, E.L. 2001. Signal peptide-selection of cDNA cloned directly from the esophageal gland cells of the soybean cyst nematode Heterodera glycines. Mol. Plant-Microbe Interact. 14: 536-544.

Waugh, M., Hraber, P., Weller, J., Wu, Y., Chen, G., Inman, J., Kiphart, D., and Sobral, B. 2000. The Phytophthora genome initiative database: Informatics and analysis for distributed pathogenomic research. Nucleic Acids Res. 28: 87-90.

Wilm, M., Shevchenko, A., Houthaeve, T., Breit, S., Schweigerer, L., Fotsis, T., and Mann, M. 1996. Femtomole sequencing of proteins from polyacrylamide gels by nano-electrospray mass spectrometry. Nature 379: 466-469.

\section{WEB SITE REFERENCES}

http://www.oardc.ohio-state.edu/phytophthora/supp.htm; Supplementary data for this article.

http://www.jic.bbsrc.ac.uk/Sainsbury-Lab/david-baulcombe/ Services/vigsprotocol.htm; Description and protocols for the binary PVX system.

http://www.cbs.dtu.dk/services/SignalP-2.0; The SignalP v2.0 server. http://www.oardc.ohio-state.edu/phytophthora/pexfinder; Description of PexFinder.

Received October 14, 2002; accepted in revised form March 12, 2003. 


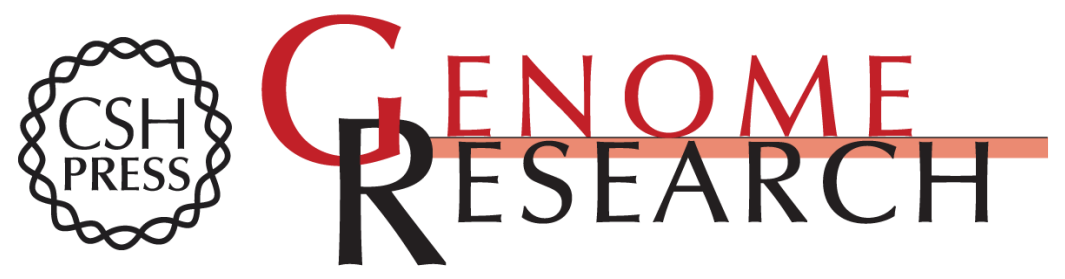

\section{EST Mining and Functional Expression Assays Identify Extracellular Effector Proteins From the Plant Pathogen Phytophthora}

Trudy A. Torto, Shuang Li, Allison Styer, et al.

Genome Res. 2003 13: 1675-1685

Access the most recent version at doi:10.1101/gr.910003

Supplemental http://genome.cshlp.org/content/suppl/2003/06/12/13.7.1675.DC1
Material

References This article cites 48 articles, 11 of which can be accessed free at:

http://genome.cshlp.org/content/13/7/1675.full.html\#ref-list-1

\section{License}

Email Alerting

Receive free email alerts when new articles cite this article - sign up in the box at the Service top right corner of the article or click here.

\section{Affordable, Accurate Sequencing.}

